See Article page 93 in the July 2020 issue.

\section{Commentary: MR is bad!}

\author{
Alexander A. Brescia, MD, MSc, and \\ Steven F. Bolling, MD on behalf of the Michigan \\ Mitral Research Group (MMRG)
}

In an extensive review, ${ }^{1}$ Badhwar summarizes the momentum behind transcatheter mitral valve (MV) therapies in treating degenerative mitral regurgitation (DMR) and secondary, functional mitral regurgitation (FMR) and eloquently describes the multidisciplinary heart team and the future mitral specialist.

For DMR, mitral valve repair (MVr) is superior to replacement and restores life expectancy for all age groups. ${ }^{2}$ Furthermore, performing early MVr before class I indications leads to superior outcomes. ${ }^{3}$ As shown in long-term follow-up, avoiding residual and recurrent MR after $\mathrm{MVr}$ is paramount to a positive outcome. ${ }^{4}$ Consequently, the threshold for replacement of DMR and transcatheter substitutes is extremely high. To summarize, early repair of DMR and avoidance of residual and recurrent MR lead to success. Outcomes and guidance for transcatheter MV therapies for DMR will be no different.

For FMR, the evidence remains unresolved. While Fattouch and colleagues ${ }^{5}$ and Chan and colleagues ${ }^{6}$ each found positive outcomes with the addition of MVr to coronary artery bypass grafting for FMR, the Cardiothoracic Surgical Trials Network (CTSN) investigators found no advantage of $\mathrm{MVr}$ over replacement in the primary end point. ${ }^{7}$ However, these 2 positive trials report $\geq 2+$ recurrent MR in $0 \%$ and $4 \%$ of patients after $\mathrm{MVr}$, compared with $33 \%$ at 1 year and $59 \%$ at 2 years in the CTSN trial. Closer inspection of the CTSN trial has revealed that a "good" repair appeared to be superior to replacement, which was superior to a "bad" repair. Transcatheter MV therapy results for FMR

\footnotetext{
From the Department of Cardiac Surgery, University of Michigan, Ann Arbor, Mich. Disclosures: Dr Brescia is supported by the National Research Service Award postdoctoral fellowship (no. 5T32HL076123). Dr Bolling reported no conflicts of interest.

The Journal policy requires editors and reviewers to disclose conflicts of interest and to decline handling or reviewing manuscripts for which they may have a conflict of interest. The editors and reviewers of this article have no conflicts of interest.

Received for publication May 12, 2020; revisions received May 12, 2020; accepted for publication May 13, 2020; available ahead of print May 31, 2020

Address for reprints: Alexander A. Brescia, MD, MSc, Department of Cardiac Surgery, University of Michigan, Frankel Cardiovascular Center, 1500 E. Medical Center Dr, Ann Arbor, MI 48109 (E-mail: abrescia@med.umich.edu).

J Thorac Cardiovasc Surg 2022;164:e29-30

$0022-5223 / \$ 36.00$

Copyright () 2020 by The American Association for Thoracic Surgery https://doi.org/10.1016/j.jtcvs.2020.05.055
}

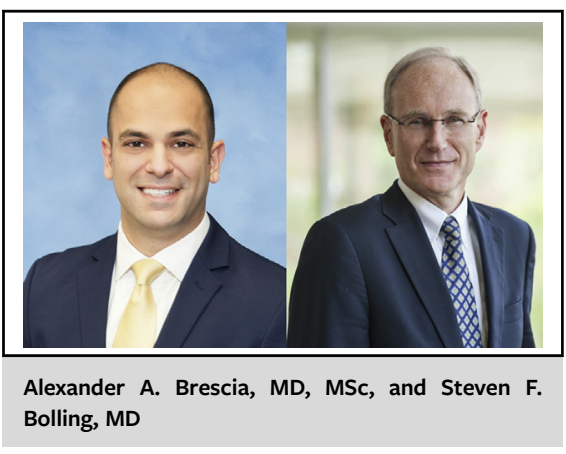

CENTRAL MESSAGE

Regardless of the approach to mitral valve therapy (transcatheter or surgical), the most important determinant of successful repair is avoidance of residual and recurrent mitral regurgitation.

are no different. Whereas MITRA-FR (Percutaneous Repair with the MitraClip Device for Severe Functional/Secondary Mitral Regurgitation; negative outcome for FMR clip) reported a $17 \%$ rate of $\geq 3+$ recurrent MR at 12 months, ${ }^{8}$ COAPT (Cardiovascular Outcomes Assessment of the MitraClip Percutaneous Therapy for Heart Failure Patients with Functional Mitral Regurgitation; positive outcome for FMR clip) reported $1 \%$ at 24 months. ${ }^{9}$ Although Badhwar correctly proposes that FMR is not amenable to a onesize-fits-all approach, data from these trials suggest that recurrent MR is bad-for all etiologies and pathoanatomic presentations (Table 1 ).

A significant volume-outcome relationship has been shown for surgical MVr over the past 2 decades. Unsurprisingly, the volume-outcome effect has been substantially stronger at the surgeon rather than hospital level. Recent analyses have shown that transcatheter MV therapies are no different, as operator experience for transcatheter $\mathrm{MVr}$ was associated with improved procedural success, time, avoidance of complications, and achieving $\leq 1+$ residual MR. ${ }^{10}$ For transcatheter MV therapies, volume still predicts outcome.

Any therapy with at least almost as good of outcomes as another, better tolerated by patients, and potentially requiring a flatter learning curve will ultimately prevailtechnology replaces technique. As we move into the next era of MV intervention, transcatheter techniques, with 
TABLE 1. Surgical and transcatheter trials for FMR in heart failure

\begin{tabular}{|c|c|c|c|c|c|c|}
\hline \multirow[b]{2}{*}{ Trial } & \multirow[b]{2}{*}{ Intervention } & \multirow[b]{2}{*}{ Control } & \multirow[b]{2}{*}{ Follow-up, mo } & \multicolumn{2}{|c|}{ Recurrent MR } & \multirow{2}{*}{$\begin{array}{c}\text { Main outcomes for } \\
\text { mitral repair }\end{array}$} \\
\hline & & & & $2+$ or worse & $\overline{3+\text { or worse }}$ & \\
\hline \multicolumn{7}{|c|}{ Positive studies for repair of FMR } \\
\hline Fattouch et al, $2009^{5}$ & $\begin{array}{l}\mathrm{CABG}+\mathrm{MVr} \\
(\mathrm{n}=48)\end{array}$ & $\begin{array}{l}\text { CABG } \\
\quad(\mathrm{n}=54)\end{array}$ & $\begin{array}{l}\text { Mean } \\
32 \pm 18\end{array}$ & $0 \%$ & $0 \%$ & $\begin{array}{l}\text { Lower NYHA class, LVEDD, } \\
\text { LVESD, PAP, and LA size }\end{array}$ \\
\hline $\begin{array}{l}\text { Chan et al } \\
\quad \text { (RIME), } 2012^{6}\end{array}$ & $\begin{array}{l}\mathrm{CABG}+\mathrm{MVr} \\
\quad(\mathrm{n}=34)\end{array}$ & $\begin{array}{l}\text { CABG } \\
\qquad(\mathrm{n}=39)\end{array}$ & 12 & $4 \%$ & $0 \%$ & $\begin{array}{l}\text { Greater improvement in peak } \\
\text { oxygen consumption and in } \\
\text { LVESVI, MR volume, and } \\
\text { BNP reduction (study } \\
\text { stopped early) }\end{array}$ \\
\hline $\begin{array}{l}\text { Stone et al } \\
\quad(\text { COAPT }), 2018^{9}\end{array}$ & $\begin{array}{l}\text { MitraClip + GDMT } \\
\quad(\mathrm{n}=302)\end{array}$ & $\begin{array}{l}\text { GDMT } \\
\qquad(\mathrm{n}=312)\end{array}$ & 24 & $23 \%$ & $1 \%$ & $\begin{array}{l}\text { Lower all-cause mortality } \\
(29 \% \text { vs } 46 \%) \text { and rate of } \\
\text { hospitalization for heart } \\
\text { failure }(36 \% \text { vs } 68 \%)\end{array}$ \\
\hline \multicolumn{7}{|c|}{ Negative studies for repair of FMR } \\
\hline $\begin{array}{l}\text { Goldstein et al } \\
\quad(\mathrm{CTSN}), 2016^{7}\end{array}$ & $\begin{array}{l}\mathrm{MVr}+/-\mathrm{CABG} \\
\quad(\mathrm{n}=126, \text { repair } \\
\text { arm of trial })\end{array}$ & & $\begin{array}{l}12 \\
24\end{array}$ & $\begin{array}{l}33 \% \\
59 \%\end{array}$ & $\begin{array}{l}4 \%(\text { all } 4+) \\
14 \%\end{array}$ & $\begin{array}{l}\text { No difference in LVESVI or } \\
\text { survival between repair and } \\
\text { replacement } \\
\text { Moderate }(2+) \text { or worse } \\
\text { recurrent MR worse in } \\
\text { repair at } 1 \text { y }(33 \% \text { vs } 2 \%) \\
\text { and } 2 \text { y }(59 \% \text { vs } 4 \%)\end{array}$ \\
\hline $\begin{array}{l}\text { Obadia et al } \\
\text { (MITRA-FR), } 2018^{8}\end{array}$ & $\begin{array}{l}\text { MitraClip + GDMT } \\
\quad(\mathrm{n}=152)\end{array}$ & $\begin{array}{l}\text { GDMT } \\
\qquad(\mathrm{n}=152)\end{array}$ & 12 & $49 \%$ & $17 \%$ & $\begin{array}{l}\text { Composite outcome of death } \\
\text { or unplanned } \\
\text { hospitalization did not } \\
\text { differ } \\
\text { 1-y echocardiographic } \\
\text { follow-up data only } \\
\text { available in } 97 / 152(64 \%) \\
\text { patients }\end{array}$ \\
\hline
\end{tabular}

$M R$, Mitral regurgitation; $F M R$, functional mitral regurgitation; $2+M R$, moderate; $3+M R$ or worse, moderate-to-severe or severe; $C A B G$, coronary artery bypass grafting; $M V r$, mitral valve repair; $N Y H A$, New York Heart Association; $L V E D D$, left ventricular end diastolic diameter; $L V E S D$, left ventricular end systolic diameter; PAP, pulmonary artery pressure; $L A$, left atrial; RIME, Randomized Ischemic Mitral Evaluation; LVESVI, left ventricular end systolic volume index; BNP, brain natriuretic peptide; COAPT, Cardiovascular Outcomes Assessment of the MitraClip Percutaneous Therapy for Heart Failure Patients with Functional Mitral Regurgitation; GDMT, guideline-directed medical therapy; CTSN, Cardiothoracic Surgical Trials Network; MITRA-FR, Percutaneous Repair with the MitraClip Device for Severe Functional/Secondary Mitral Regurgitation.

much less biologic impact, will succeed because we will intervene in earlier patients with less heart failure, leading to more "heart success." Second, we will "guess better." Instead of evaluating MV anatomy in an empty heart on bypass, transcatheter technology allows us to examine and intervene on the MV in a fully-loaded beating heart under 3-dimensional transesophageal echocardiogram. Nonetheless, while using improved technology to "guess better," all mitral specialists must never forget that mitral valve biology has not changed. No matter the etiology or procedural approach, success will remain defined by elimination and avoidance of MR. MR is bad!

\section{References}

1. Badhwar V. Transcatheter mitral valve intervention: consensus, quality, and equipoise. J Thorac Cardiovasc Surg. 2020;160:93-8.

2. Watt TMF, Brescia AA, Murray SL, Burn DA, Wisniewski A, Romano MR, et al. Degenerative mitral valve repair restores life expectancy. Ann Thorac Surg. 2020; 109:794-801.

3. Suri RM, Vanoverschelde J-L, Grigioni F, Schaff HV, Tribouilloy C, Avierinos J-F, et al. Association between early surgical intervention vs watchful waiting and outcomes for mitral regurgitation due to flail mitral valve leaflets. JAMA. 2013;310:609-16.

4. David TE, David CM, Tsang W, Lafreniere-Roula M, Manlhiot C. Long-term results of mitral valve repair for regurgitation due to leaflet prolapse. J Am Coll Cardiol. 2019;74:1044-53.

5. Fattouch K, Guccione F, Sampognaro R, Panzarella G, Corrado E, Navarra E, et al. POINT: efficacy of adding mitral valve restrictive annuloplasty to coronary artery bypass grafting in patients with moderate ischemic mitral valve regurgitation: a randomized trial. J Thorac Cardiovasc Surg. 2009;138: 278-85.

6. Chan KMJ, Punjabi PP, Flather M, Wage R, Symmonds K, Roussin I, et al. Coronary artery bypass surgery with or without mitral valve annuloplasty in moderate functional ischemic mitral regurgitation: final results of the randomized ischemic mitral evaluation (RIME) trial. Circulation. 2012;126:2502-10.

7. Goldstein D, Moskowitz AJ, Gelijns AC, Ailawadi G, Parides MK, Perrault LP, et al. Two-year outcomes of surgical treatment of severe ischemic mitral regurgitation. $N$ Engl J Med. 2016:374:344-53.

8. Obadia J-F, Messika-Zeitoun D, Leurent G, Iung B, Bonnet G, Piriou N, et al. Percutaneous repair or medical treatment for secondary mitral regurgitation. $N$ Engl J Med. 2018;379:2297-306.

9. Stone GW, Lindenfeld J, Abraham WT, Kar S, Lim DS, Mishell JM, et al. Transcatheter mitral-valve repair in patients with heart failure. N Engl J Med. 2018; 379:2307-18.

10. Chhatriwalla AK, Vemulapalli S, Szerlip M, Kodali S, Hahn RT, Saxon JT, et al. Operator experience and outcomes of transcatheter mitral valve repair in the United States. J Am Coll Cardiol. 2019;74:2955-65. 